\title{
Influence of different harvest dates and ripening periods on fruit quality and oil characteristics of Fuerte avocados
}

\author{
${ }^{1}$ Aml R. M. Yousef and ${ }^{2}$ Minar Mhmoud M. Hassaneine \\ ${ }^{1}$ Horticultural Crops Technology Department, Agriculture and Biological Division, National \\ Research Center, Dokki, Egypt. \\ ${ }^{2}$ Fats and Oils Department, Food Industries and Nutrition Division, National Research Center, \\ Dokki, Egypt.
}

\begin{abstract}
Ripening and procedures of highly enriched and specialized oil in Fuerte avocado (persea americana Mill.) during storage at $20^{\circ} \mathrm{C}$ were investigated. Three different harvest dates (early, middle and late) of avocado fruits were evaluated. Fruits were collected in first November, December and January of the season $2007-2008$ at one-month intervals. Samples were kept for 7 days under controlled temperature $\left(20^{\circ} \mathrm{C}\right)$ to ripe. Fruit quality, ripening properties, oil characteristics, fatty acid composition of avocado fruit as well as a comparison between avocado and olive (cv. Coratina) oils were investigated with respect to the harvesting and postharvest (ripening) period. The dry matter (DM) of Fuerte avocado fruits were increased gradually, while, fruit firmness (FF), soluble solid concentration (SSC) and titratable acidity (TA) showed a gradual and significant decrease during the various dates of harvest and ripening period at $20^{\circ} \mathrm{C}$, respectively. Skin fruit color had a slight significant differences between color parameters $L^{*}, a^{*}$, $b^{\star}$ and Chroma $\left(C^{\star}\right)$ and Hue angle $\left(h^{\star}\right)$ values. Respiration rate had a significant increase at the different harvest dates reaching its peak value at $1^{\text {st }}$ Dec. and finally decreased. Oil characteristics (oil content (OC), acid value (AV), peroxide value (PV), iodine value (IV), color index $(\mathrm{Cl})$, refractive index $(\mathrm{RI})$ and fatty acid composition (FA)) of avocado oils at different harvest dates and ripening at $20^{\circ} \mathrm{C}$ were discussed. Oil content of Fuerte avocado fruit was increased to the $1^{\text {st }}$ Dec. then decreased at the $1^{\text {st }}$ Jan., Meanwhile, the oil content of Coratina olive was increased from the $1^{\text {st }}$ Nov. to the $1^{\text {st }}$ Jan. The AV of Fuerte and Coratina cultivars decreased, meanwhile PV increased. There was a change in the unsaturation character (IV) for Fuerte and Coratina varieties. RI had no noticeable change occur during all of the months for both varieties. Oleic and linolenic acids showed increase values in avocado oil in comparison with olive oil. Moreover, Palmitic and linoleic acids, showed high value in olive oil than avocado oil.
\end{abstract}

Keywords: Avocado (persea americana Mill.), fruit quality, ripening period, oil characteristics, Fatty acid composition and olive oils.

\section{INTRODUCTION}

Avocado is a climacteric fruit characterized by a surge in ethylene production at the onset of ripening. This climacteric increase in ethylene production is associated with hastened ripening. Ripening or softening of avocado does not occur during maturity on the tree, but takes place several days after fruits have been picked. It seems that there is a flow of inhibitive components from leaves to the fruit, preventing fruit from softening on the tree (Werman and Neeman, 1987). Avocado is one of the most rapidly ripening of fruit often completely ripening after 5-7 days following harvest (Seymour and Tucker, 1993). Fruit maturity and picking time are determined according to external markers (color and size), or by measuring oil content in the flesh (Werman and Neeman, 1987)

Ripening of climacteric fruit involves a series of coordinated metabolic events which alter their anatomy, biochemistry, physiology, and gene expression (Giovannoni, 2001). These alterations affect many characteristics, such as color, flavor and texture of the fruit (Cai et. al., 2006).

Fruit firmness at later picking dates was lower and the rate of softening during storage was faster compared with earlier picking dates (Zauberman et.. al., 1986). Fruit softening is closely connected with cell wall modifications caused by some cell wall degrading enzymes (Fischer and Bennett, 1991).Moreover, softening is an important part of the 
ripening process, and it is well documented that change in cell walls accompany fruit softening(Brummell and Harpster ,2001)

Color is an important food quality parameter. It affects consumer acceptance, the perception of sweetness and flavor and can even evoke emotional feelings in humans (Ornelas et. al., 2008; Crisosto et. al., 2003 and Bayarri et. al., 2001). During Fuerte ripening color play an important role in the perception of overall quality. We may be able to manipulate coloring in some way to better co-ordinate softening and color change (Woolf and Laing, 1996).

Avocado fruit played an important role in oil production consumed edible lipids in the world are extracted either from the endosperm of oil seeds or from pricarp of oil fruit, mainly oil palm and olive trees. Another important oil fruit is avocado (Frega et. al., 1990). Oil content increases in the mesocarp a few weeks after the fruit sets and can be correlated after wards, with the age of fruit as oil increases in the mesocarp ,water content decreases by the same amount, so that the total percentage of oil and water remains constant during fruit life, nevertheless, biosynthesis of the triglycerides doesn't start at the beginning of physiological life at the fruit (Gaydou et. al.,1987).Furete avocado contains between 94 and 98\% triglycerides and between 2 and 6\% complex lipids. Crude avocado oil is a viscous liquid with storage brown-green pigmentation. After refining the oil color turns light yellow with a greenish tint, the green pigmentation is due to the chlorophylls $a$ and $b$ exiting in the skin at high concentration and which is present in pulp (Jacobs-berg, 1988)

Fatty acid composition is the characteristic feature by which the quality and possible uses of given oil can be directly delivered (Gaydou et. al., 1987). Avocado oil is rich in olleate, which has a low content of saturated fatty acids, and this makes it appropriate for direct human consumption, as well as excellent fat in diet designed to reduce cardiovascular disease (Gurr, 1992)

The aim of this study was to investigate the influence of different harvest dates and postharvest ripening period on fruit quality criteria, ripening changes, oil characteristics attributes and fatty acid composition of Fuerte avocado fruits. In addition, there are a comparison studies between Furete avocado oil and Coratina olive oil during ripening process.

\section{MATERIAL AND METHODS}

This experiment was conducted on avocado fruit (persea americana Mill.) cv. Fuerte which were selected from a private orchard (Nemous) at El katta district, Giza region, Egypt during 2007 and 2008 season. Mature fruits were harvested at three different dates; at the first week of November, December and January from trees 20 years old, similar in growth vigor and subjected to the common horticultural treatments.

Fruits: Avocado fruits were transported within a few hours to the laboratory of the Agriculture Development System (ADS) project in the Faculty of Agriculture, Cairo University. Fruits were graded, washed, air-dried and packed in carton boxes and stored at $20^{\circ} \mathrm{C}$ to ripen for seven days in control temperature rooms (Bally sectional prefab walls, Ins.USA) with relative humidity (90-95\%). Three representative replicates for each sampling dates were taken for physical and chemical analysis during each harvest date and after ripening at $20^{\circ} \mathrm{C}$ and each replicate consisted of 5 fruits as follow:

Fruit quality assessments: avocado dry matter percent in avocado fruits were determined and calculated. Fruit firmness was measured using Ametek pressure tester, fitted with an $8 \mathrm{~mm}$ hemispherical probe (probe penetration $2 \mathrm{~mm}$ ), the results calculated as Newton units. Total acidity (expressed as oleic acid) was determined by titrating $5 \mathrm{ml}$ juice with $0.1 \mathrm{~N}$ sodium hydroxide using phenolphthalein as an indicator, SSC content was measured to using a T/C hand refractometer Instrone, Brix-readings 0-30 ranges (Model 10430, Bausch and Lomb Co. Calif., USA). Ascorbic acid content was determined using 2, 5-6 dichlorophenol indophenols' titration methods as described by (A.O.A.C., 1990).

Respiration rate: fruits of each sampling date were weighed and placed in 2-liter jars at $20^{\circ} \mathrm{C}$. The jars were sealed for $4 \mathrm{hrs}$ with a cap and a rubber septum. $\mathrm{O}_{2}$ and $\mathrm{CO}_{2}$ samples of the headspace were removed from a septum with a syringe and injected into Servomex Inst. (Model 1450C, Food Pack Gas Analyzer) to measure oxygen and carbon dioxide production. Respiration rate was calculated as $\mathrm{mlCO}_{2} / \mathrm{kg} / \mathrm{hr}$ (Lurie and Pesis, 1992; Pesis and BenArie, 1984).

Fruit color measurement: skin color was determined and expressed as on the basis of the CIELAB color system $\left(L^{*}, a^{*}, b^{*}\right)$ using a Minolta Co., Ltd., Osaka, Japan). Hue angle and Chroma values 
were calculated from $\left(a^{*}, b^{\star}\right)$ using the methods described by (Lopez and Gomez, 2004).

\section{Oil quality assessments:}

The oil content: the percentage of oil content in the dried flesh samples was extracted by means of soxhelt fat-extraction apparatus using hexane (40$60^{\circ} \mathrm{C}$ boiling point) for the extraction, which continued about 6 hours according to (A.O.A.C. , 1980)

Oil properties: the extracted oil was analyzed for acid value as $\mathrm{mg} \mathrm{KOH} / \mathrm{g}$, peroxide value as meq $/ \mathrm{kg}$ and iodine value as $\mathrm{g} / 100 \mathrm{~g}$ of oil were determined as described in (A.O.A.C., 1990). Color index was determined according to (Yoshida and Kajimoto, 1989), while refractive index determination at $40{ }^{\circ} \mathrm{C}$ was assessed according to (Mordret, et. al., 1985)

Determination of fatty acid by GLC: The avocado oil samples were converted to their fatty acid methyl esters by transesterification using $5 \%$ hydrogen chloride in dry methanol (Chrisite, 1973). Hewelett Packard Model 6890 gas chromatograph was employed for the analysis of fatty acid methyl esters under the following conditions: column INNO wax capillary column (polyethylene glycol), $30.0 \mathrm{~m} \mathrm{x}$ $530 \mu \mathrm{m}$, film thickness $1.0 \mu \mathrm{m}$; colum was operated isothermally at $280^{\circ} \mathrm{C}$; injecyion temperature, $280^{\circ} \mathrm{C}$; split ratio 8:1; split flow $120 \mathrm{ml} / \mathrm{min}$;gas saver, $20 \mathrm{ml}$ / min; and carrier gas, $\mathrm{N}_{2}$ with flow rate $15 \mathrm{ml} / \mathrm{min}$; FID detector temperature $280^{\circ} \mathrm{C}$; hydrogen flow rate, $30 \mathrm{ml} / \mathrm{min}$ and air flow rate, $300 \mathrm{ml} /$ min.Peak areas were determined by electronic integrator and percentage composition of fatty acids was automatically calculated. Standard mixture of fatty acids methyl esters was also chromatographed under the same operating conditions.

Avocado and olive oils comparison: oil content, acid value, peroxide value, lodine value and Fatty acid composition of avocado and olive oils during ripening at $20^{\circ} \mathrm{C}$ were measured by the same methods for comparison.

Statistical analysis: The design for this work was a Completely Randomized Design (CRD) with three replications. Data were analyzed with the analysis of variance (ANOVA) procedure of M-STATIC program reported by (Snedecor and Cochran ,1980).

\section{RESULTS AND DISCUSSION}

Fruit quality assessments:-Change of dry matter of Fuerte avocado fruits throughout the harvest dates and ripening at $20^{\circ} \mathrm{C}$ for 7 days have been shown in (Table ,1). The dry matter content were increased gradually during different harvest dates from the $1^{\text {st }}$ November $(24.23 \%)$ recording its highest value at $1^{\text {st }}$ January (30.51\%). Meanwhile this rate of increase was dropped from December $(29.45 \%)$ to the $1^{\text {st }}$ January (26.18\%) during ripening at $20^{\circ} \mathrm{C}$ for 7 days.

In this respect, (Ranney et al., 1992) recorded that dry weight of flesh fruit continued to increase throughout the sampling period. Moreover, (Gaydou et.al.,1987) reported that moisture content of avocado mesocarp was decreased steadily with increasing lipid content during the 12-39 weeks after flowering.

Table 1: Fruit quality properties of avocado fruits at different harvest dates and after one week storage at $20^{\circ} \mathrm{C}$.

\begin{tabular}{ccccccc}
\hline Treatments & Dry matter (\%) & Firmness (N) & SSC (\%) & Resp.rate $\left(\mathrm{ml} / \mathrm{kg} / \mathrm{h}^{-1)}\right)$ & Acidity (\%) & V.C (mg/100gm) \\
\hline Harvest dates & $24.23 \mathrm{~b}$ & $7.24 \mathrm{a}$ & $10.93 \mathrm{a}$ & $18.03 \mathrm{~d}$ & $1.09 \mathrm{a}$ & $10.44 \mathrm{a}$ \\
$1^{\text {st }}$ Nov. & $29.63 \mathrm{a}$ & $67.12 \mathrm{~b}$ & $8.4 \mathrm{ab}$ & $30.09 \mathrm{a}$ & $1.02 \mathrm{a}$ & $10.30 \mathrm{ab}$ \\
$1^{\text {st }}$ Dec. & $30.51 \mathrm{a}$ & $54.28 \mathrm{C}$ & $7.93 \mathrm{~b}$ & $26.36 \mathrm{~b}$ & $1.02 \mathrm{a}$ & $9.46 \mathrm{a} \mathrm{b}$ \\
$1^{\text {st }}$ Jan. & & & & & \\
Ripening at 0 & & & & & \\
$1^{\text {st }}$ Nov. & $29.45 \mathrm{a}$ & $19.98 \mathrm{~d}$ & $8.33 \mathrm{~b}$ & $25.30 \mathrm{bc}$ & $0.64 \mathrm{~b}$ & $9.22 \mathrm{ab}$ \\
$1^{\text {st }}$ Dec. & $29.50 \mathrm{a}$ & $12.56 \mathrm{e}$ & $6.70 \mathrm{~b}$ & $33.16 \mathrm{a}$ & $0.56 \mathrm{~b}$ & $8.82 \mathrm{ab}$ \\
$1^{\text {st }}$ Jan. & $26.18 \mathrm{ab}$ & $8.03 \mathrm{f}$ & $3.81 \mathrm{C}$ & $22.35 \mathrm{c}$ & $0.53 \mathrm{~b}$ & $7.15 \mathrm{~b}$ \\
\hline
\end{tabular}

Significant differences at L.S.D. P $>0.05$

Changes in fruit firmness $(\mathrm{N})$ of Fuerte avocado fruits due to different harvest dates and ripening at $20^{\circ} \mathrm{C}$ for 7 days from the $1^{\text {st }}$ Nov. to $1^{\text {st }}$ Jan. was illustrated in (Table, 1) resulted progressive and significant decline in fruit firmness reached to the least firm at $1^{\text {st }}$ Jan. $(54.28,8.03 \mathrm{~N})$ Meanwhile, decrease of fruit firmness percentage was higher at ripening stage compared with harvest dates. These results are in agreement with (Swarts, 1980) who showed that the firmness of avocado fruit was declined rapidly while holding at room temperature. Moreover, (Zauberman et. al., 1986) added that firmness of avocado fruit at later picking dates was lower and the rate of softening during storage was faster compared with 
earlier picking dates. The change in SSC of Fuerte avocado fruit subjected to different harvest dates and storage at $20^{\circ} \mathrm{C}$ for 7 days are shown in Table (1). Soluble solid concentration had a little and gradual decrease from $1^{\text {st }}$ Nov. to $1^{\text {st }}$ Jan. reached the minimum value at $1^{\text {st }}$ Jan. $(7.93 \%)$. The same trend was observed while the fruit ripened at $20^{\circ} \mathrm{C}$ recorded the least value at the $1^{\text {st }}$ Jan. (3.81\%).

Respiration rate of avocado fruit expressed as mass of $\mathrm{CO}_{2}$ in $\mathrm{ml} / \mathrm{kg} / \mathrm{h}^{-1}$ is shown in (Table, 1 ). There was a progressive significant increase in respiration rate of Fuerte avocado fruit during different harvest dates from the first of Nov., reaching a peak value at $1^{\text {st }}$ Dec.(30.09 mg kg-1 $\left.\mathrm{hr}^{-1}\right)$ and finally decreased at1 ${ }^{\text {st }}$ Jan. (26.35 mg kg-1 $\mathrm{hr}^{-1}$ ) as well as after ripening at $20^{\circ} \mathrm{C}$ for 7 days $\left(33.16,22.35 \mathrm{mg} \mathrm{kg}-1 \mathrm{hr}^{-1}\right)$, respectively.

Similarly, Fuerte avocado fruits placed directly at $20^{\circ} \mathrm{C}$ showed atypical climacteric respiratory pattern, which was associated with ripening (Eaks, 1976). There was no significant differences in titratable acidity \% (TA) were detected among different harvest dates of Fuerte avocado fruit from $1^{\text {st }}$ Nov. to $1^{\text {st }}$ Jan. as shown in $(T a b l e, 1)$. Similar results were obtained when the fruits ripened at $20^{\circ} \mathrm{C}$ for 7 days nevertheless, there was a significant decrease in TA for avocado fruit of each harvest date when ripening at $20^{\circ} \mathrm{C}$ for one week. In this concern, (Jacobi et.al, 2000) recorded that titratable acidity decreased as mangoes ripen.

Regarding ascorbic acid content (VC), it is observed that its content was decreased by different harvest dates and storage at $20^{\circ} \mathrm{C}$ for a week. The rate of decrease had a little significant recoded the least value at $1^{\text {st }}$ Jan. $(9.46,7.15)$ respectively. These results are in harmony with those reported by (Ania, 1990) and( Zambrano, 2000). They reported that ascorbic acid content decline during ripening and storage of mango fruits.

Changes of skin color of avocado fruits cv. Furete during different dates of harvest $\left(1^{\text {st }}\right.$ Nov., $1^{\text {st }}$ Dec.and $1^{\text {st }}$ Jan.) and storage at $20^{\circ} \mathrm{C}$ are shown at $($ Table, 2$)$ in three measurement scales $\left(L^{*}, a^{*}, b^{*}\right)$. Chroma $\left(C^{*}\right)$ and hue $\left(h^{*}\right)$ were calculated and conversed from $a^{*}$ and $b^{*}$. There were a slight significant differences between $L^{*}, a^{*}, b^{*}$ and $C^{*}$ and $\mathrm{h}^{*}$ values at different harvest dates and storage at $20^{\circ} \mathrm{C}$.
Fruit lightness $\left(L^{*}\right)$ had a gradual decrease at harvest and ripe at $20^{\circ} \mathrm{C}$ reached the lowest values at $1^{\text {st }}$ Jan $(40.15,38.14)$ respectively. Meanwhile, Chroma decreased gradually during different dates of harvest recorded 8.42 at $1^{\text {st }}$ Jan then it had gradual increase in storage at $20^{\circ} \mathrm{C}$. Hue angle of avocado fruit showed a slight significant decreased at harvest dates $\left(1^{\text {st }}\right.$ Nov., $1^{\text {st }}$ Dec .and $1^{\text {st }}$ Jan.) reached the lowest values at $1^{\text {st }}$ Jan (29.71). On the other side the value of Hue angle increased from $1^{\text {st }} \operatorname{Nov}(32.6)$ to $1^{\text {st }}$ Dec (34.27) then decreased at $1^{\text {st }}$ Jan (27.26) respectively throughout ripening at $20^{\circ} \mathrm{C}$. (Ninio, et. al., 2003) reported that the color change of mango is a reliable parameter to determine the extent of fruit ripening.

Oil quality assessments:-Oil content (OC), acid value (AV), peroxide value (PV), iodine value (IV) ,color index $(\mathrm{Cl})$ and refractive index $(\mathrm{RI})$ of avocado oils at different harvest dates and storage at $20^{\circ} \mathrm{C}$ were recorded in Table (3). It is clear that the oil content of Fuerte are 49.59, 51.85 and $38.78 \%$ at November, December and January respectively. This shows that the oil content is increased only at December then decreased at January. While the oil content at harvest dates increased only at $1^{\text {st }}$ Dec.(47.5\%) and then decrease at $1^{\text {st }}$ Jun.(42.22\%) With reference to $A V$ it increased to $4.9 \mathrm{mg} / \mathrm{g}$ at $1^{\text {st }}$ Jan. while it decreased to 3.35 and 3.9 at $1^{\text {st }}$ Nov. and December respectively. On the other side, the $\mathrm{AV}$ decreased during ripening at $20^{\circ} \mathrm{C} \quad(1.15,0.99$ and 0.5 ) from $1^{\text {st }}$ Nov. to $1^{\text {st }}$ Jan.

Concerning the PV it was found that it increased from 10.35 at $1^{\text {st }}$ Nov. to 12.45 and 14.56 at $1^{\text {st }}$ Dec. and $1^{\text {st }}$ Jan. during harvest dates. Meanwhile, during storage at $20^{\circ} \mathrm{C}$ the PV was increased from 12.0 at $1^{\text {st }}$ Nov., 14.48 at $1^{\text {st }}$ Dec. and reached to its maximum value (16.38) at $1^{\text {st }}$ Jan.

The color of the oil is an important physical characteristic, color changes as express as color index $(\mathrm{Cl})$. In general $\mathrm{Cl}$ was decreased from $1^{\text {st }}$ Nov. to $1^{\text {st }}$ Jan. In both harvest dates and during storage at $20^{\circ} \mathrm{C}$ with values ranging from $272.21,219.45$ and 174.19 in the harvest dates and from 294.21, 270.91 and 224.36 in the Furete avocado oils. The unsaturation character (IV) of the avocado oil was measured to follow any changes occur. 
Agric. Biol. J. N. Am., 2010, 1(6): 1223-1230

Table (2): Skin color parameters ( $L^{*}, a^{*}, b^{*}$ and chroma and hue angle) of avocado fruits measured at different harvest dates and one week ripe at $20^{\circ} \mathrm{C}$.

\begin{tabular}{|c|c|c|c|c|c|}
\hline \multirow{2}{*}{ Treatments } & \multicolumn{5}{|c|}{ Color measurements } \\
\hline & $L^{*}$ & $a^{*}$ & $b^{*}$ & $C^{*}$ & $h^{0}$ \\
\hline $\begin{array}{l}\text { Harvest dates } \\
1^{\text {st }} \text { Nov. }\end{array}$ & $46.40 \mathrm{a}$ & $14.55 \mathrm{a}$ & $25.39 \mathrm{a}$ & $29.27 a$ & $38.40 \mathrm{a}$ \\
\hline $1^{s t} \mathrm{Dec}$. & $46.18 \mathrm{a}$ & $5.36 \mathrm{~b}$ & $9.69 \mathrm{~b}$ & $11.08 \mathrm{~b}$ & $31.14 \mathrm{ab}$ \\
\hline $1^{\text {st }} \mathrm{Jan}$ & $40.15 b c$ & $3.88 \mathrm{bc}$ & $7.47 \mathrm{bc}$ & $8.42 \mathrm{bc}$ & $29.71 a b$ \\
\hline \multicolumn{6}{|c|}{ Ripening at $20^{\circ} \mathrm{C}$} \\
\hline $1^{\text {st }}$ Nov. & $44.40 \mathrm{ab}$ & $3.40 \mathrm{c}$ & $5.90 \mathrm{c}$ & $6.80 \mathrm{c}$ & $32.60 \mathrm{ab}$ \\
\hline $1^{\text {st }}$ Dec. & $42.32 \mathrm{abc}$ & $4.59 \mathrm{bc}$ & $7.67 \mathrm{bc}$ & $8.94 \mathrm{bc}$ & $34.27 \mathrm{ab}$ \\
\hline $1^{\text {st }}$ Jan. & $38.14 \mathrm{c}$ & $3.49 \mathrm{bc}$ & $7.33 \mathrm{bc}$ & $8.11 \mathrm{bc}$ & 27.26 b \\
\hline
\end{tabular}

Significant differences at L.S.D. P $>0.05$

Table (3): Oil quality properties of avocado fruit measured at different harvest dates and one week storage at $20^{\circ} \mathrm{C}$.

\begin{tabular}{|c|c|c|c|c|c|c|}
\hline \multirow[b]{2}{*}{ Treatments } & \multicolumn{6}{|c|}{ Oil characteristics } \\
\hline & $\begin{array}{c}\text { Oil } \\
\text { percent }\end{array}$ & $\begin{array}{c}\text { Acid } \\
\text { value }\end{array}$ & $\begin{array}{c}\text { Peroxide } \\
\text { value }\end{array}$ & $\begin{array}{l}\text { Iodine } \\
\text { value }\end{array}$ & $\begin{array}{l}\text { Color } \\
\text { index }\end{array}$ & $\begin{array}{c}\text { Refractive } \\
\text { index }\end{array}$ \\
\hline \multicolumn{7}{|c|}{ Harvest dates } \\
\hline $1^{\text {st }}$ Nov. & $45.68 a b$ & $3.35 \mathrm{~b}$ & $10.35 d$ & $93.1 \mathrm{a}$ & $272.21 \mathrm{~b}$ & $1.462 \mathrm{a}$ \\
\hline $1^{\text {st }}$ Dec. & $47.5 \mathrm{ab}$ & $3.9 a b$ & $12.45 \mathrm{c}$ & $90.9 a$ & $219.45 b$ & $1.463 \mathrm{a}$ \\
\hline $1^{\text {st }}$ Jan. & $42.22 \mathrm{bc}$ & $4.9 \mathrm{a}$ & $14.5 \mathrm{~b}$ & 85.53 b & $174.19 \mathrm{~b}$ & $1.462 \mathrm{a}$ \\
\hline \multicolumn{7}{|c|}{ Ripening at $20^{\circ} \mathrm{C}$} \\
\hline $1^{\text {st }}$ Nov. & $49.59 \mathrm{a}$ & $1.15 \mathrm{c}$ & $12.0 \mathrm{~cd}$ & 84.95 b & 294.21 b & $1.464 \mathrm{a}$ \\
\hline $1^{s t}$ Dec. & $51.85 \mathrm{a}$ & $0.99 \mathrm{c}$ & $14.48 \mathrm{~b}$ & $84.75 \mathrm{~b}$ & $270.91 \mathrm{a}$ & $1.457 \mathrm{a}$ \\
\hline $1^{\text {st }}$ Jan. & $38.78 \mathrm{c}$ & $0.5 \mathrm{c}$ & $16.38 \mathrm{a}$ & 83.25 b & $224.36 \mathrm{~b}$ & $1.453 \mathrm{a}$ \\
\hline
\end{tabular}

Significant differences at L.S.D. P $>0.05$

It was found that IV of avocado fruits at harvest dates was $93.1,90.9$ and 85.53 from $1^{\text {st }}$ Nov. to $1^{\text {st }}$ Jan. respectively, while it ranged $84.95,84.75$ and 83.25 in Fuerte fruits from $1^{\text {st }}$ Nov. to $1^{\text {st }}$ Jan.

There is no noticeable changes were occurred in RI during all the months of harvest dates and storage at $20^{\circ} \mathrm{C}$ for a week. The value of the RI nearly constant 1.4 during all the harvest dates and ripening at $20^{\circ} \mathrm{C}$.

Determination of fatty acid composition:-The fatty acid composition of avocado oil is given in Table (4) palmitic acid, palmitoleic oleic and linoleic acids were found to be the major fatty acids. In general, oleic acid was the only fatty acid which increased continuously from $1^{\text {st }}$ Nov. to $1^{\text {st }}$ Jan. in different harvest dates and in ripening at $20^{\circ} \mathrm{C}$ for one week with percentages ranging from 65.5 to $71.21 \%$ in harvest dates and from 66.3 to $72.6 \%$ in storage at $20^{\circ} \mathrm{Cfor}$ one week. (Hulme, 1971) noted that the proportion of oleic acid increased faster than the other fatty acids by retarding the harvest. The percentage of palmitic acid decreased from $18.5 \%$ to $16.0 \%$ in harvest dates from $1^{\text {st }}$ Nov. to $1^{\text {st }}$ Jan. while in storage at $20^{\circ} \mathrm{Cfor}$ one week the palmitic acid decreased from 16.0 to $14.5 \%$ from $1^{\text {st }}$ Nov.to $1^{\text {st }}$ Jan. A regular decrease was also shown for linolenic acid from 4.54 to $2.0 \%$ in harvest dates from $1^{\text {st }}$ Nov.to $1^{\text {st }}$ Jan. and from 3.0 to $1.4 \%$ in ripe at $20^{\circ} \mathrm{Cfor}$ one week from $1^{\text {st }}$ Nov. to $1^{\text {st }}$ Jan.

There was a decrease in the percent of linoleic acid for ripe at $20^{\circ} \mathrm{Cfor}$ one week from $1^{\text {st }}$ Nov., ${ }^{1 \text { st }}$ Dec. and then increase was observed in $1^{\text {st }}$ Jan. However, in $1^{\text {st }}$ Jan., the value of linoleic acid in at $20^{\circ} \mathrm{C}$ for one week of avocado Fuerte was not higher than its value in $1^{\text {st }}$ Nov. In contrast, linoleic acid steadily decreased from $1^{\text {st }}$ Nov. to $1^{\text {st }}$ Jan. in harvest dates It has been reported by (Gaydou et. al, 1987) that as the fruits developed the contents of fatty acids and triglycerides increased. 
Agric. Biol. J. N. Am., 2010, 1(6): 1223-1230
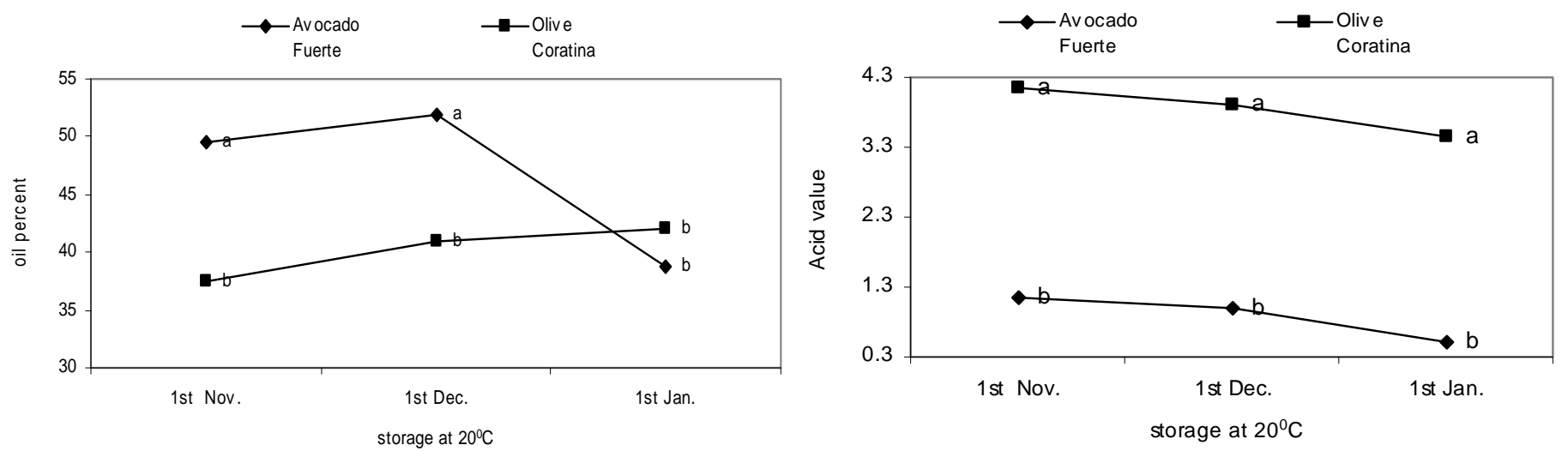

Fig. (1): Oil content of Furete avocado and Coratina Olive Fruit storage at $20^{\circ} \mathrm{C}$ for one week influenced by different harvest dates ( $1^{\text {st }}$ Nov., $1^{\text {st }}$ Dec.and $1^{\text {st }}$ Jan.).
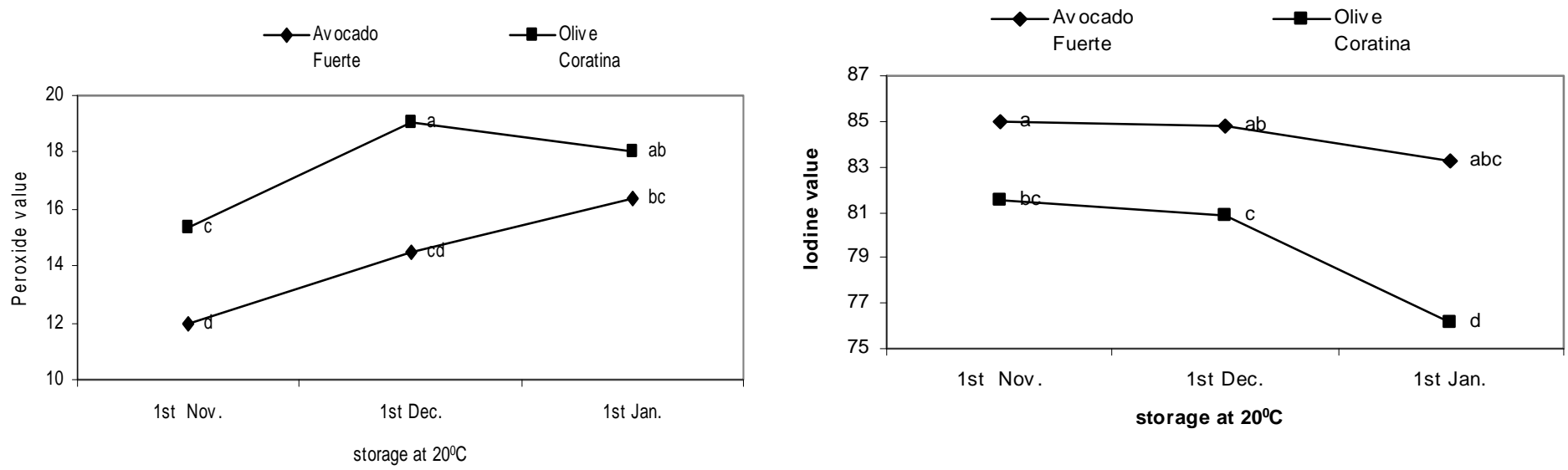

Fig. (3): Peroxide value of Furete avocado and Coratina olive oil fruit storage at $20^{\circ} \mathrm{Cfor}$ one week influenced by different harvest dates ( $1^{\text {st }}$ Nov., $1^{\text {st }}$ Dec.and $1^{\text {st }}$ Jan.)
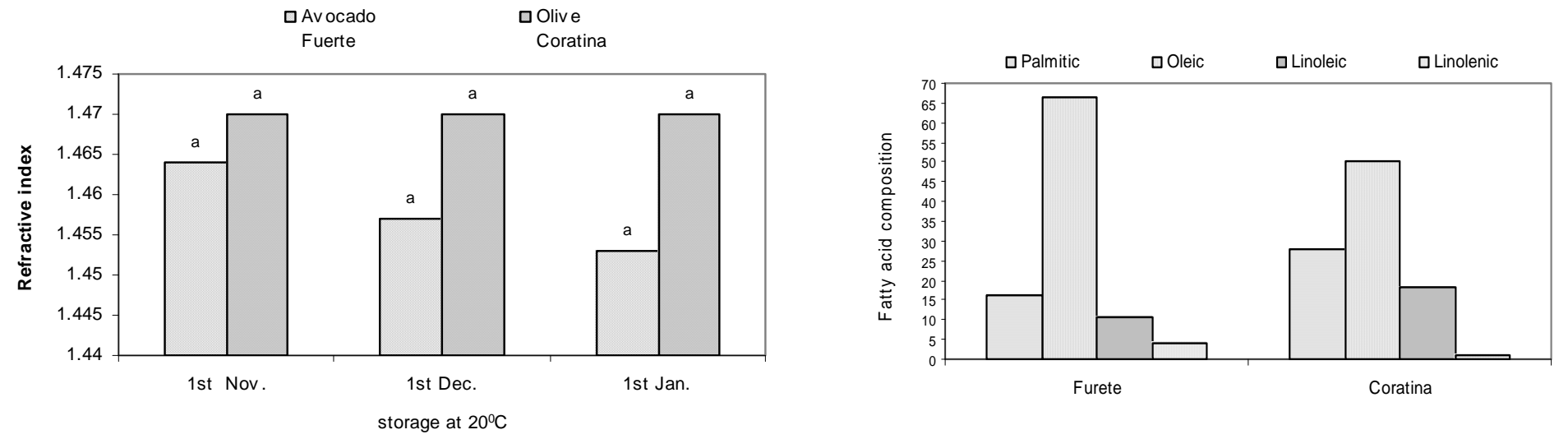

Fig.(5): Refractive index of Furete avocado and Coratina Olive oil from fruit storage at $20^{\circ} \mathrm{Cfor}$ one week influenced by different harvest dates $\left(1^{\text {st }}\right.$ Nov., $1^{\text {st }}$ Dec.and $1^{\text {st }}$ Jan.) 
Effect of different harvest dates on avocado and olive oils properties during storage at $20^{\circ} \mathrm{C}$ for one week: The results cited in (Fig's,1 and 2) was increased from $1^{\text {st }}$ Nov.to $1^{\text {st }}$ Dec., however a rapid decrease was observed for the level of oil in $1^{\text {st }}$ Jan. In olive Coratina variety, the amount of oil increased from $1^{\text {st }}$ Nov. to $1^{\text {st }}$ Jan. The acid value of Fuerte and Coratina varieties was decreased from $1^{\text {st }}$ Nov.to ${ }^{\text {st }}$ Jan.

The peroxide value increased in Fuerte cultivar from $1^{\text {st }}$ Nov. to $1^{\text {st }}$ Jan. while Coratina cultivar increased only from $1^{\text {st }}$ Nov. to $1^{\text {st }}$ Dec (.Fig.,3) There was as showed that the oil content of Fuerte avocado fruit

small change in the IV for Fuerte variety from $1^{\text {st }}$ Nov. to $1^{\text {st }}$ Dec. and then a slight decrease was observed in $1^{\text {st }}$ Jan., while a regular decrease was show for Coratina variety from $1^{\text {st }}$ Nov.to $1^{\text {st }}$ Jan. (Fig.,4) With reference to RI there was no noticeable change occur during all of the months for both varieties (Fig.,5) The fatty acid composition of avocado (Furete) and olive (Coratina) are given in Fig.(6). Palmitic, stearic, oleic, linoleic and linolenic acids were found to be major fatty acids in two oils. Oleic and linolenic acids, showed increase value in avocado oil in comparison to olive oil. While Palmitic and linoleic acids, showed high value in olive oil than avocado oil.

Table (4): Fatty acid composition of avocado fruit measured at different harvest dates and one week storage at $20^{\circ} \mathrm{C}$.

\begin{tabular}{|c|c|c|c|c|c|}
\hline \multirow{2}{*}{ Treatments } & \multicolumn{5}{|c|}{ Fatty acid composition } \\
\hline & Palmitic & Palmitoliec & Oleic & Linoleic & Linolenic \\
\hline \multicolumn{6}{|c|}{ Harvest dates } \\
\hline $1^{\text {st }}$ Nov. & 18.50 & 4.46 & 65.50 & 7.00 & 4.54 \\
\hline $1^{s t} \mathrm{Dec}$ & 17.00 & 5.100 & 67.60 & 6.83 & 3.47 \\
\hline $\begin{array}{l}1^{\text {st }} \text { Jan. } \\
\text { Ripening at }\end{array}$ & 16.00 & 4.86 & 71.21 & 5.93 & 2.00 \\
\hline $1^{\text {st }}$ Nov. & 16.00 & 4.00 & 66.30 & 10.70 & 3.00 \\
\hline $1^{s t} \mathrm{Dec}$ & 14.50 & 5.00 & 68.40 & 9.51 & 2.59 \\
\hline $1^{\text {st }} \mathrm{Jan}$. & 10.85 & 4.50 & 72.60 & 10.75 & 1.40 \\
\hline
\end{tabular}

\section{CONLUSION}

The present data showed that there were minor differences in fruit quality for 'Fuerte' avocados due to different harvested dates and ripening period (Table 1). Early and late date fruit showed similar patterns for respiration and climacteric behaviour. Fruits picked during the middle date reached a higher rate of respiration rates compared to those harvested during early and late date. Late date fruits were fewer firms, SSC, acidity and ascorbic acid compared to fruits from earlier date, also during ripening period. Results showed a significant decrease in color parameters ( $L^{*}, a^{*}, b^{*}$ and chroma and hue angle) of avocado fruits at different harvest dates and one week ripe at $20^{\circ} \mathrm{C}$ (Table, 2). The results are important in providing information about the oil and fatty acid composition of avocado fruit during maturation to decide the proper harvesting time and nutritional aspects. In addition, this study indicates that the oil extracts from the fruit of avocado cv. Furete of three different harvest dates contain high \% of oil and high acid value. High AV (4.9 at $1^{\text {st }}$ Jan in harvest dates) is indicator of large free fatty acid content in crude oil. During fruit softening, FFA is formed as a result of lipolytic activity of internal enzymes. External mycetic enzymes are also involved (Werman and Neeman, 1987). Also avocado oil contain high amount of oleic acid, which it is a great importance in terms of their nutritional implication and the effect on oxidative stability of oils (Aparicio, et al., 1999) and low levels of linolenic acid. High levels of this acid can produce an un favourable odour and taste in oil (Baydar, et. al., 2007).

\section{REFERENCES}

Ania, O.J. (1990). Physic-chemical changes in African mango during normal storage ripening Food Chem., 36:205-212.

A.O.A.C. (1980). Official methods of analysis (13th Ed.) Association of Official Analytical Chemists. Washington, DC. U.S.A.

A.O.A.C. (1990). Official methods of analysis of the $5^{\text {th }}$ ed published by Association of Official Analytical Chemists. $5^{\text {th }}$ ed published by Association of Official Analytical Chemists. Washington, DC. U.S.A. 
Aparicio, R.; Roda, L.; Albi, MA. And Gutierrez, F. (1999)"'Effect of various compounds on virgin olive oil stability measured by Rancimat." J. Agric Food Chem.

47: 4150- 4155.

Baydar, G.N.; Ozkan, G. and Cetin, S.E.(2007)"Characterization of grape seed and pomace oil extracts " Grasas Y Aceites 58 (1): 29-33.

Bayarri, S.; Calvo, C.;. Costell, E. and Dur'an,L. (2001). "Influence of color perception of sweetness and fruit flavor of fruit drinks." Food Sci. Tech. Int., 7: 399- 404.

Brummell, D. A. and M. H. Harpster (2001). Cell wall metabolism in fruit softening and quality and its manipulation in transgenic plant. Plant Mol. Biol.,47:311340.

Cai,C.;K.S.Chen;W.P.Xu;W.S.Zhang;X.Li and I. Ferguson (2006).Effect of 1-MCP on postharvest quality of loquat fruit. Post.Biol.and Techn.40:155-162.

Chrisite, W. (1973). Lipid analysis 1st Ed., pergamonpress, oxford, Newyork, Toronto and Sydney, pp.87- 96.

Crisosto, C.H.; Crisosto, G.M. and. Metheney,P. (2003). Consumer acceptance of 'Brooks' and 'Bing' cherries is mainly dependent on fruit SSC and visual skin color. Postharvest Biol. and Techn., 28: 159-167.

Eaks, I. L. (1976) "Ripening, chilling injury and respiratory response of Hass and Fuerte avocado fruits at $20{ }^{\circ} \mathrm{C}$ following chilling." J. Amer. Soc. Hort. Sci., 10:538-540.

Fischer, R. L. and Bennett, A.B (1991)"'Role of cell wall hydrolases in fruit ripening." Annu. Rev. Plant Physiology Plant Mol.Biol.,42:675-703.

Frega. N.; Bocc, F.; Lercker, G. and Bortolomeazzi, R.(1990)."Lipid composition of some avocados cultivars". International J.of Food Sci., 3:197-204.

Gaydou,E.M.; Lozano, Y. and.Ratovohery,J. (1987)."Triglyceride and Fatty acid composition in the mesocarp of Persea americana during fruit development." Phytochm., 26 (6):1595-1597.

Giovannoni, J. (2001). Molecular regulation of fruit ripening. Annu. Rev. Plant Physiol. Plant Mol. Biol., 52: 725-749.

Gurr, M.I.(1992)."Dietary Lipids and coronary heart disease :old evidence, new perspective." Progress in Lipid Research,3(3):195-243.

Hulme, A.C.(1971)"The biochemistry of Fruit and their Products." vol.2, p.29.New York Academic press.

Jacobi. E.; A.Macrae and S.E.Hetherington (2000).Effects of hot air conditioning of Kensington mango fruit on response to hot water treatment. Post.Biol.and Techn.21;39-49.

Jacobs- berg, B.( 1988)" Avocado oil a literature survey Belgian." J. of Food Chem. and Biotech., 43(4) :115

Jacobi, E.; Macrae, A. and Hetherington, S. E. (2000)." Effects of hot air conditioning of Kensington mango fruit on the response to hot water treatment." Post. Biol. and Techn., 21 : 39-49.

Lopez C.A.F. and Gomez, P. A. (2004)."Comparison of color indexes for tomato ripening." Hort., Brasileira 22: 534547

Lurie, S. and Pesis,E. (1992). "Effect of acetaldehyde and anaerobiosis as post harvest treatment on the quality of peaches and nectarines." Post. Biol. and Technol., 1: 317-326.

Mordret, F.; Ajana,H. and Gauchet,C.(1985)."Fractionation of unsaponifiable matter by HPLC-isolation of sterol fraction."Rev. Fr. Crops Gras.32: 305-310.

Ninio, E.; Lewinsohn,; Y.Mizrahi and Sitrit, Y. (2003).' Changes in sugars. acids and volatiles during ripening of Koubo (Cereus Peruvianus(L)Miller) fruit." J.of Agricultural and Food Chem., 51:425-429.

Ornelas-Paz, J. De, J. ; Yahia, E. M.and Gardeab, A.A. (2008). "changes in external and internal color during postharvest ripening of 'Manila' and 'Ataulfo' mango fruit and relationship with carotenoids content determined by liquid chromatography-APcl+-time-of-flight mass spectrometry." Post. Biol. and Tech. 50: 145-152

Pesis, E. and Ben-Arie,R. (1984). "Involvement of acetaldehyde and ethanol accumulation during induced deastringency of persimmon fruits." J. Food Sci., 49:896899.

Ranny, G.; Gillelte,A. ; Mclntyre,O. ; Vasquez,C.A. and .wilson, E. ( 1992). "Physiological maturity and percent dry matter of California avocado." Proc. of Second World Avocado, Congress, pp. 379-385.

Seymour, G. B. and Tucker, G.A. (1993). Avocado In G.B.S Seymour, J. Tayler, and G.A. Tucker (Eds.), Biochemistry of fruit ripening (pp.53-81).London: Chapman and Hall.

Snedecor, G.W. and Cochran,W.G.1980. Statistical Methods. (7 th Ed) lowa State Univ. press Ames.Low USA.

Swarts, D. H. (1980). "A method of determining the ripeness of avocado." Citrus and Subtropical Fruit Research Institute, No., 90:15 -18. (c.f. Hort. Abst., 1981, 1(8):6544).

Werman, M.J. and Neeman, T. (1987)."Avocado oil production and chemical characteristics" J. Am.Oil Chem.Soc., 64 (2): $279-232$.

Woolf, A.B. and Laing, W.A. (1996)." Avocado fruit skin fluorescence following hot water treatments and pretreatments. "J. Am. Soc. Hort. Sci., 121: 147-151.

Yoshida,H.and Kajimoto,G.(1989)."Effects of microwave energy on tocopherols of soybean seeds." J. Food Sci., 54:596-1600.

Zauberman, G.; Fuchs,Y. and Akerman,M. (1986). "Peroxides activity in avocado stored at chilling temperatures." Scientia Hort., 26: 261-265.

Zambrano, J.;W. Materano and Brichno (2000). Influence of storage period on postharvest characteristics of five varieties of mango Mangifera indica. L Universidad del Zuli, 17(2):14-172 (c.f. Hort. Abst., 2002, 72(1):278). 